\title{
Chrysis monticola Linsenmaier, 1999 (Hymenoptera, Chrysididae), a new species for the European fauna
}

\author{
Paolo Rosa $^{1 *}$, Alain Livory ${ }^{2}$, David Baldock ${ }^{3}$
}

\begin{abstract}
Chrysis monticola Linsenmaier, 1999, previously known for northern Africa, was collected in different sites in Algarve and Baixo Alentejo in Portugal. A list of the known species of the C. aestiva group is given and Chrysis amurensis Semenov, 1967 is transferred from the C. aestiva group to the C. splendidula group.
\end{abstract}

Key words: Chrysididae, Chrysis monticola, Chrysis aestiva group, Portugal.

Riassunto - Chrysis monticola Linsenmaier, 1999 (Hymenoptera, Chrysididae), una nuova specie per la fauna europea.

Chrysis monticola Linsenmaier, 1999, finora conosciuta solo su esemplari del Nord Africa, è stata raccolta in differenti località dell'Algarve e del Basso Alentejo in Portogallo. Viene proposta una checklist aggiornata delle specie del gruppo C. aestiva, e la specie Chrysis amurensis Semenov, 1967 viene trasferita dal gruppo $C$. aestiva al gruppo C. splendidula.

Parole chiave: Chrysididae, Chrysis monticola, gruppo Chrysis aestiva, Portogallo.

\section{INTRODUCTION}

In recent years, from 2000 to 2015, there has been an increasing number of entomologists collecting and studying Hymenoptera in Portugal. The main recorders have been Alain Livory, Roselyne Coulomb and David Baldock; all the other colleagues are mentioned in the acknowledgements. Thanks to this teamwork, about 1200 species of Hymenoptera and 70 species of Chrysididae have been recorded in Portugal, raising the number of known Portuguese species and subspecies to 162 (Mingo, 1994; Kuhlmann, 1996; Tussac \& Zumeta,

\footnotetext{
${ }^{1}$ Via Belvedere 8/d, 20881 Bernareggio (MB), Italia

${ }^{2}$ Rue du Docteur Lemoine 55, 50230 Agon-Coutainville, France E-mail: alain-livory@wanadoo.fr

${ }^{3}$ Nightingales, Haslemere Road, Milford, GU8 5BN Surrey, UK. E-mail: david@tiphia.eu

*Corresponding author: rosa@chrysis.net

(C) 2015 Paolo Rosa, Alain Livory, David Baldock
}

Received: 16 April 2015

Accepted for publication: 2 September 2015
2004; Oliveira, 2009; Rosa \& Soon, 2012; pers. data). The new chrysidid records for Portugal will be discussed in a separate paper, but one species is worthy to be mentioned apart, because it has not been found previously from Europe and it is one of the most outstanding species in the West Palearctic. Chrysis monticola Linsenmaier, 1999 was recently described for northern Africa (Morocco and Algeria); Alain Livory and Roselyne Coulomb collected some specimens for the first time in Europe from 2009 to 2012. After this discovery, the number of chrysidid European species is raised from 483 (Mitroiu et al., 2015) to 484.

\section{MATERIALS AND METHODS}

The terminology follows Kimsey \& Bohart (1991), and the classification of species and species groups follow Fauna Europaea (Rosa \& Soon, 2012), Linsenmaier $(1959,1999)$. Abbreviations used in the text are as follows:

$\mathrm{F} 1, \mathrm{~F} 2$, etc. $=$ flagellum 1 , flagellum 2 ;

$1 / \mathrm{w}=$ length versus width;

$\mathrm{MOD}=$ midocellus diameter;

OOL $=$ oculo-ocellar line;

$\mathrm{POL}=$ postocellar line;

$\mathrm{S} 2$ = second metasomal sternite;

$\mathrm{T} 1$ = first metasomal tergite;

$\mathrm{T} 3$ = third metasomal tergite;

$\mathrm{TFC}=$ transverse frontal carina.

Photographs of the specimens were taken with a Nikon D80 camera connected to a Togal SCZ stereomicroscope and stacked with Combine ZP software. The white calibration of the camera was applied to reduce the blue effect of the neon light of the Togal microscope.

\section{RESULTS}

\section{Examined material}

Chrysis monticola Linsenmaier was collected in Portugal in Algarve and Baixo Alentejo by A. Livory and R. Coulomb (Fig. 1). Algarve: 1, Carrapateira, vii.2009 (Fig. 2A) (P. Rosa collection); 10̄, Odeceixe (Aljezur), 


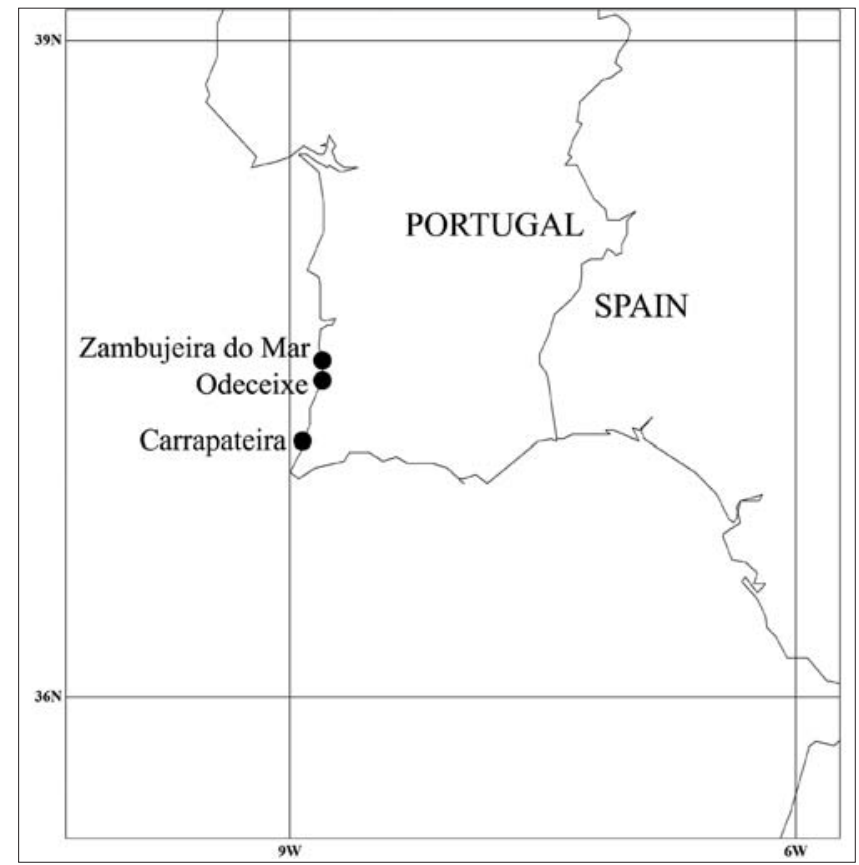

Fig. 1 - Map of the collecting localities of Chrysis monticola in southern Portugal.

vii.2009 (Fig. 2B) (P. Rosa collection); 1ठ, id., vii.2009; 1ㅇ, id. 26.vii.2009; 19, id. 26.vii.2009 (A. Livory and D. Baldock collections). Baixo Alentejo: 10̄, Zambujeira do Mar, 17.vii.2012 (A. Livory collection).

\section{Description of Chrysis monticola Linsenmaier, 1999}

Female: $7-8 \mathrm{~mm}$ (6-7 $\mathrm{mm}$ in the original description) (Fig. 3A).

Colouration: head metallic blue, frons and vertex in ocellar area greenish; pronotum, scutellum, metanotum mesopleuron, metapleuron and partially propodeum metallic red to golden-red; metasoma metallic red, T1 anteriorly metallic blue to greenish; antennae blackish, with very feeble blue metallic reflections on pedicellus and base of F1. Head: malar spaces more subparallel than in Linsenmaier line drawing (Linsenmaier, 1999: 170, fig. 224) and about 1.1 MOD long (Fig. 3B); subantennal space a little longer than 1 MOD; OOL: 2.3 MOD; POL: 2.2 MOD; TFC distinct and vaguely M-like; scapal basin medially micropunctate, with punctures confluent and forming transversal lines; clypeus medially slightly incised. Mesosoma: with large punctures and smooth intervals (Fig. $3 \mathrm{C}$ ), propodeal tooth narrow and pointing downward. Metasoma: apical teeth elongated (Fig. 3D) and spiniform, the median pair close together and the lateral well developed and pointed; pit row with relatively large and deep pits, the two median pits larger, laterally partially fused; black spots on S2 large (Linsenmaier, 1999: 170, fig. 227).

Male: 7-8 mm (Fig. 4). Differs from female by colouration: the red and golden parts of mesosoma are

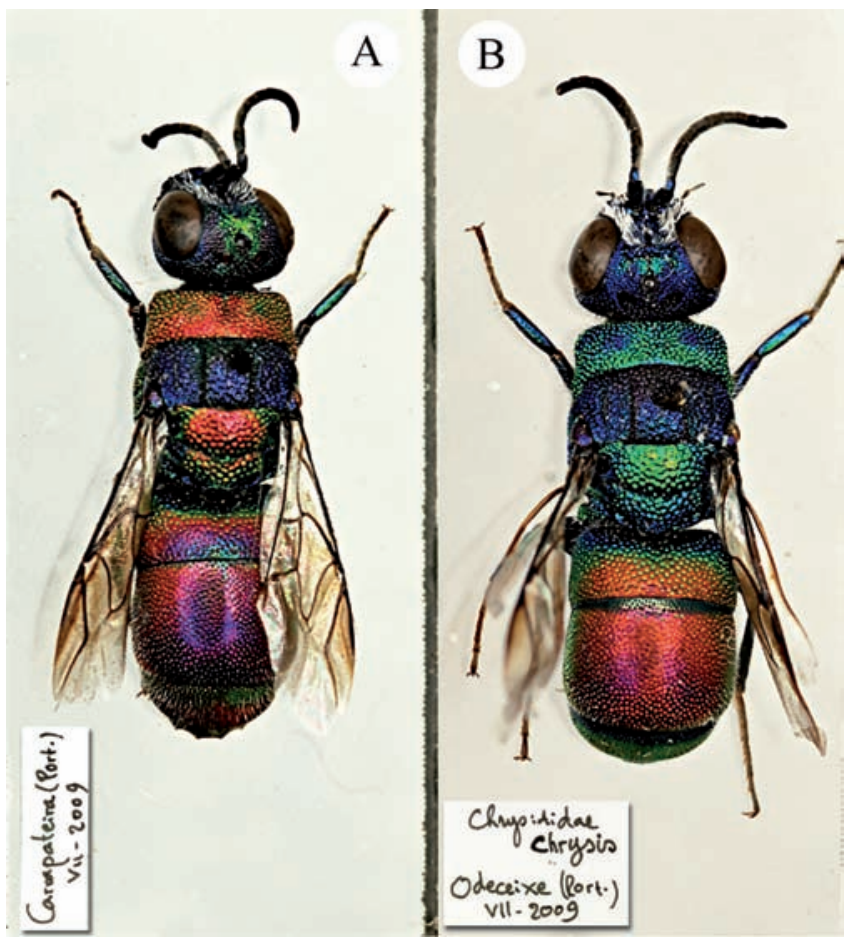

Fig. 2 - Chrysis monticola Linsenmaier, 1999. European specimens: A) female, B) male.

greenish, contrasting with the rest of head and mesonotum. In both sexes there are two greenish to bluish rounded spots laterally on pronotum. Malar spaces evidently convergent and about 1.1 MOD long; TFC distinctly M-like; scapal basin micropunctated, with long whitish hairs; apical teeth shorter and smaller, with subequal intervals.

\section{Variation and species group placement}

The European female (Fig. 2A) differs from the northern African female by narrower apical teeth and larger black spots on S2. The male (Fig. 2B) differs by pale femur and enlarged black spots on S2. Despite these small differences, the genital capsule match the genitalia of the allotype from Morocco and therefore we consider the discrepancies as intraspecific variations between different populations. Future molecular systematic analysis will possibly confirm this interpretation.

The Algerian paratype housed in the Linsenmaier collection is truly a little different, as already noticed by Linsenmaier (1999). In particular, the very reduced black spots on S2 are remarkably different. However, this variation could be related to the different environmental conditions, whereas the genital capsule matches the genital capsule of the Moroccan allotype.

Linsenmaier (1999) noticed that $C$. monticola could be included in the $C$. viridula group. We maintain the placement of $C$. monticola in the $C$. aestiva group for its general habitus, the shape of the genital capsule and other diagnostic characteristics of the species group despite its unusual and unique body colouration. 


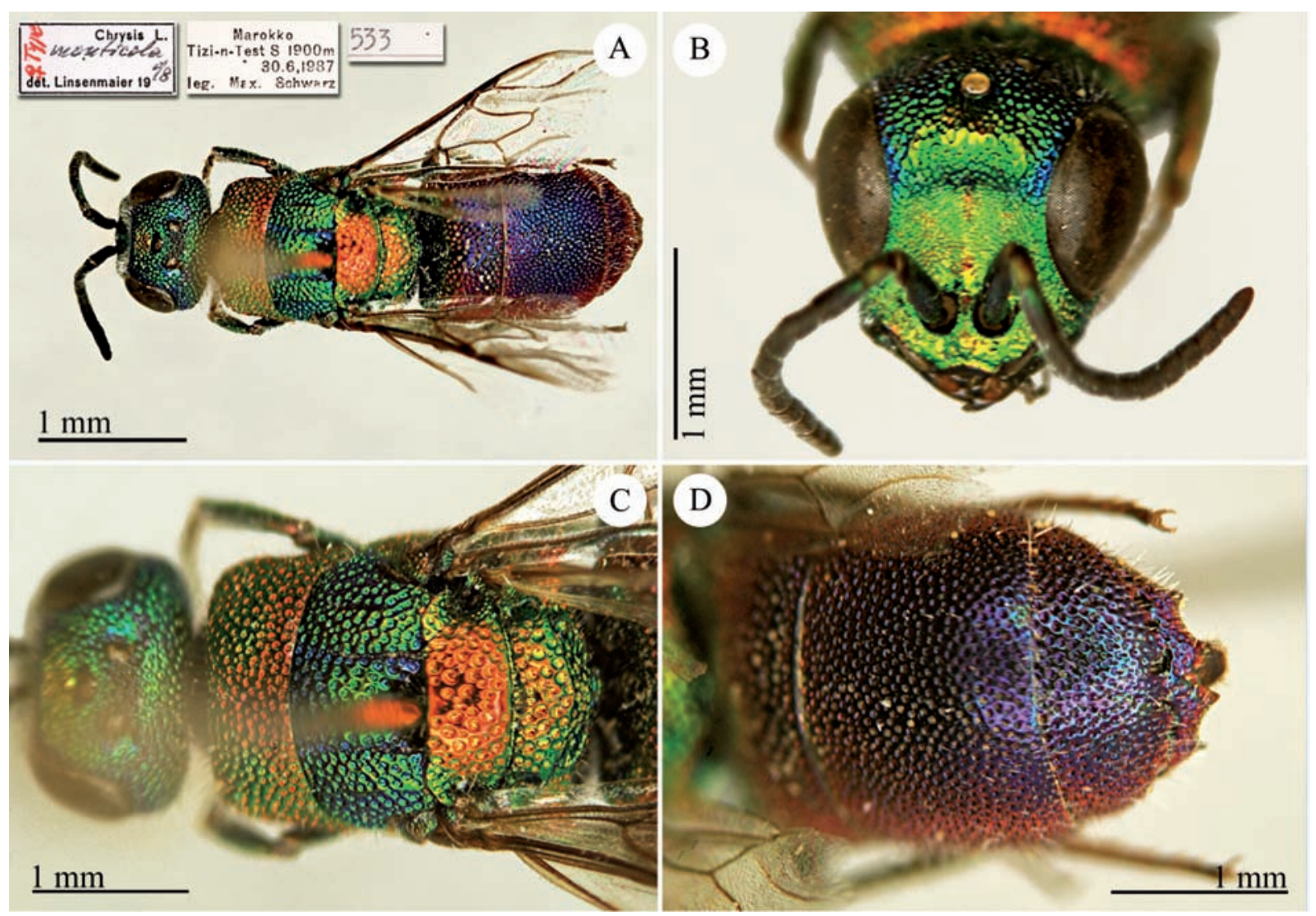

Fig. 3 - Chrysis monticola Linsenmaier, 1999, holotype female. A) general habitus, dorsal view; B) head, frontal view; C) head and mesosoma dorsal view; D) metasoma, dorsal view.

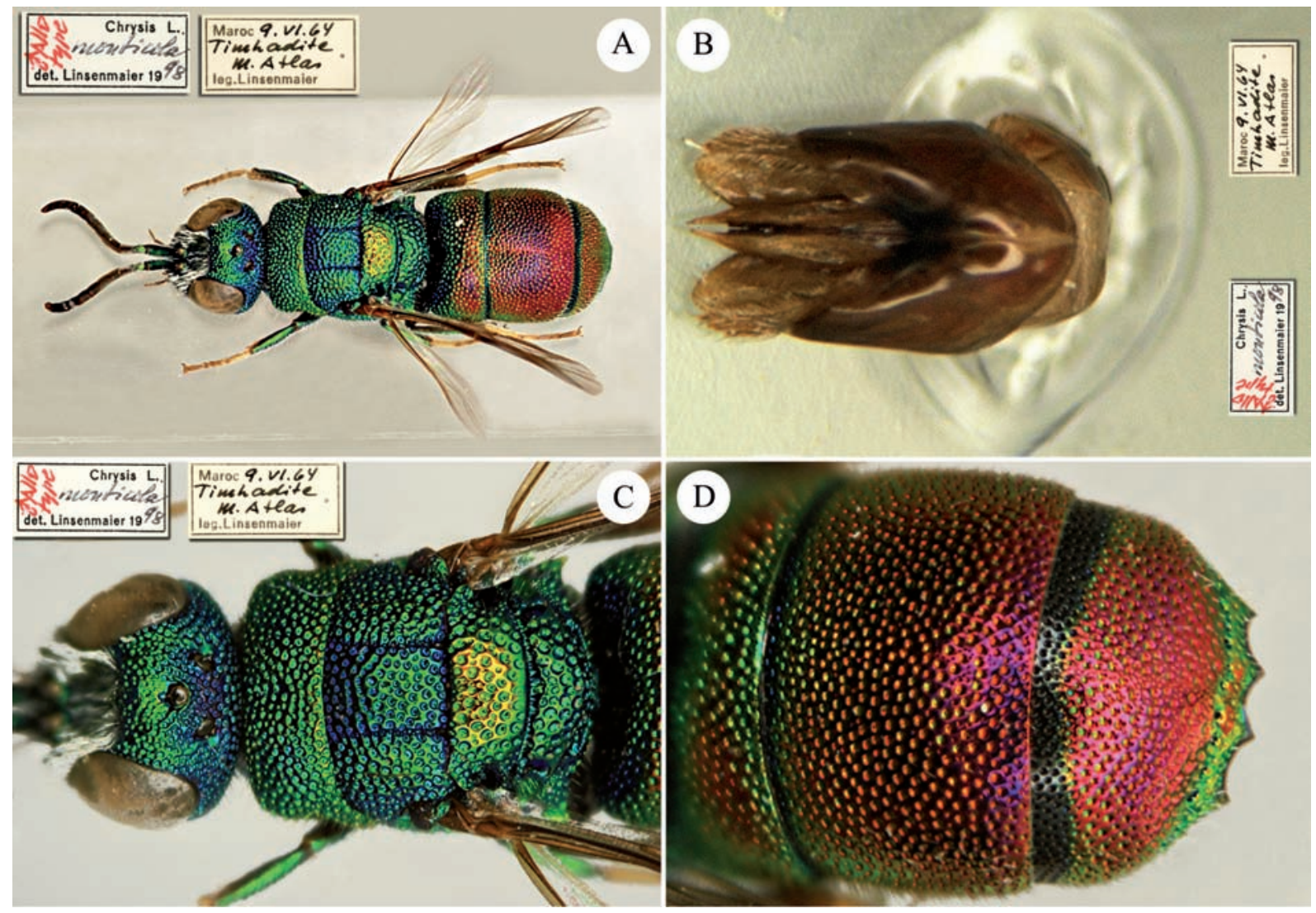

Fig. 4 - Chrysis monticola Linsenmaier, 1999, allotype male. A) general habitus, dorsal view; B) genital capsule; C) head and mesosoma dorsal view; D) metasoma, dorsal view. 


\section{Distribution}

Chrysis monticola Linsenmaier, 1999 is known from northern Africa (Morocco and Algeria) and Portugal. Based on the known records, C. monticola is a eurythermic and euryzonal species living in high mountains (it was collected at $1900 \mathrm{~m}$ ) and deserts (Tamanrasset).

\section{Phenology}

Chrysis monticola in Portugal was recorded only in July, although field research was carried out throughout the season between March and the end of September. It is likely that July is the optimal period of flight of C. monticola in Portugal. In northern Africa, it has been recorded in the High Atlas and Anti-Atlas mountains in Morocco (Tizi-n-Test, Timahdite, Ijoukak, Ait Saoun) from June to July, and in Algeria (Tamanrasset) at the end of March.

\section{Biology and habitat}

Chrysis monticola Linsenmaier was collected in three localities from North to South of the coast between Cabo de Sines and Cabo de Sao Vicente, in the Parque Natural do Sudoeste Alentejano e Costa Vicentina, the largest protected coastal area in Europe, more than $100 \mathrm{~km}$ long. The landscapes consist of rocky capes, steep or broken cliffs, interspersed with immense dunes or estuaries. These habitats conceal many endemic plants and the fauna is extremely rich. One specimen was collected on the cliffs of Zambujeira do Mar in Alentejo (Fig. 5), in a habitat of dunes and scrubland. Most of the specimens were collected further south, on the banks of the Ceixe estuary at Odeceixe, together with many other rare Hy- menoptera species. Here the dunes perched on cliffs offer a diversified network of scrubland and mobile sands that is extremely attractive to aculeate Hymenoptera. Lastly, one specimen was collected at the extreme south of Algarve, in the immense stretch of dunes of Carrapateira (Fig. 6) with its enormous clumps of Eryngium maritimum. The specimens were collected on the ground or on flowers but possible hosts were not observed. The only citation (Linsenmaier, 1959) in this species group for Mediterranean species is Pseudoanthidium lituratum (Panzer) (Megachilidae), as a possible host for Chrysis interjecta du Buysson.

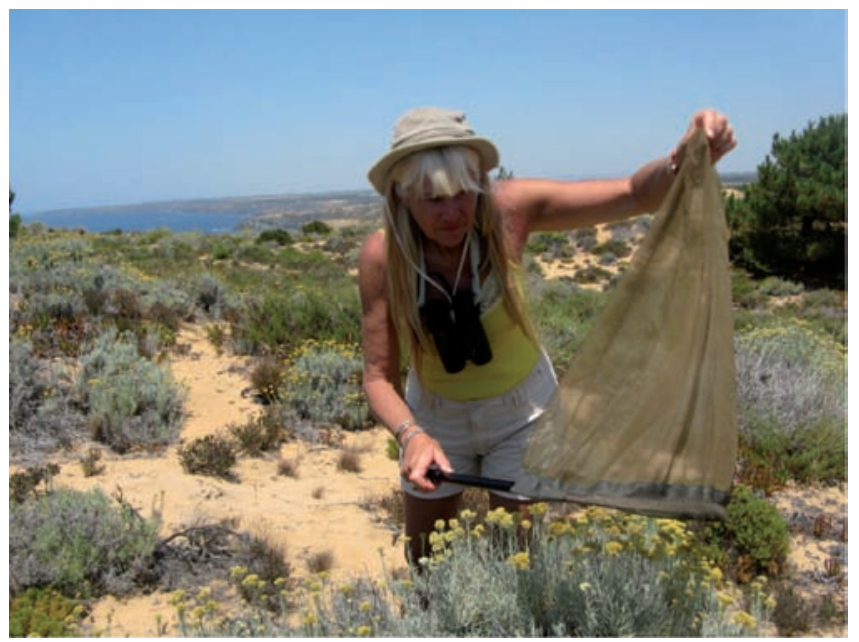

Fig. 5 - Habitat of Chrysis monticola in Zambujeira do Mar $17^{\text {th }}$ July 2012. Roselyne Coulomb hunting on Helichrysum flowers (Photo Alain Livory).

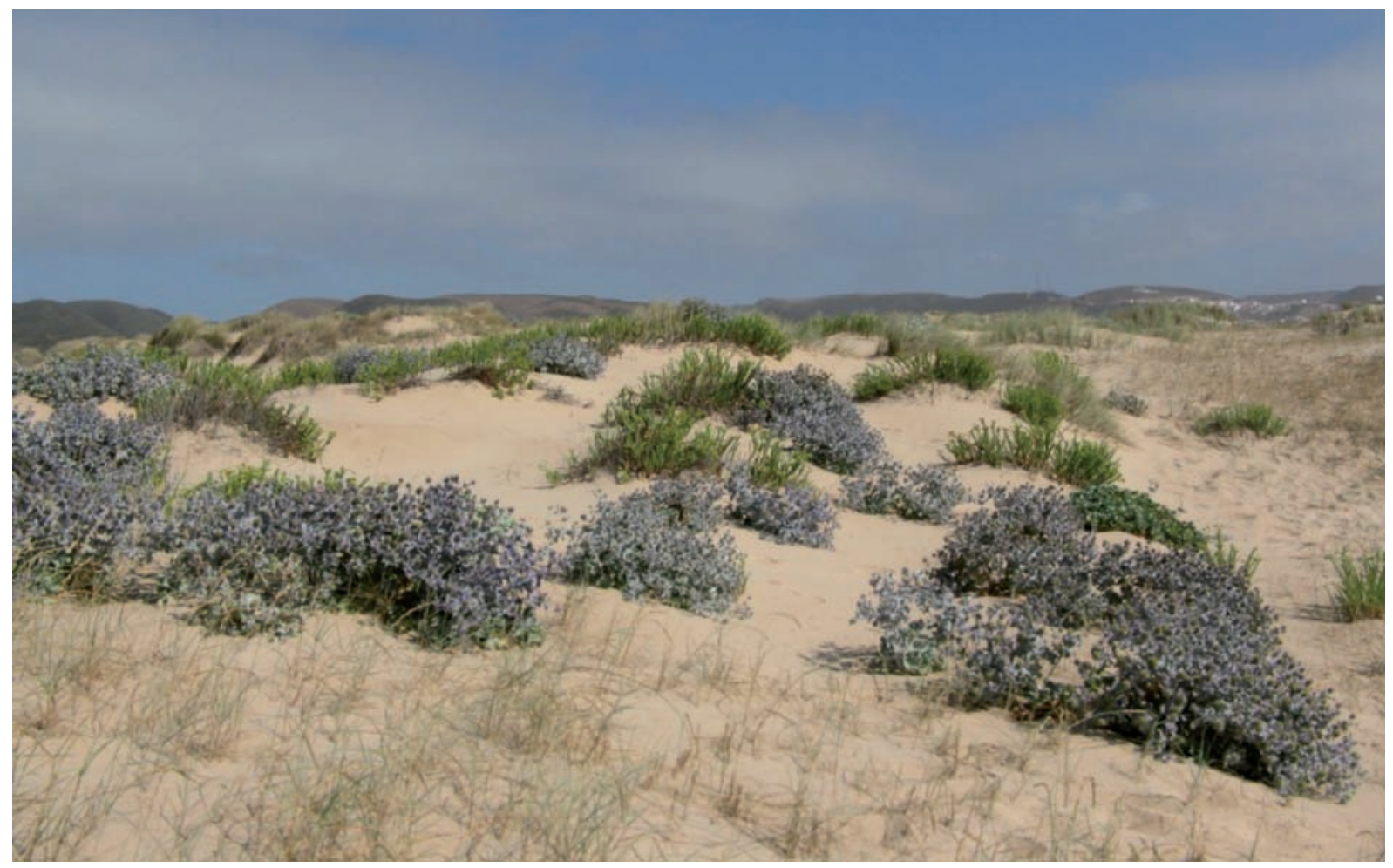

Fig. 6 - Habitat of Chrysis monticola in Carrapateira $9^{\text {th }}$ July 2009 (Photo Alain Livory). 


\section{Diagnosis of the $C$. aestiva group}

Chrysis monticola Linsenmaier, 1999 belongs to the C. aestiva group. The Chrysis aestiva group was originally established by Linsenmaier (1959) and it is characterised by: rather long F1 (1/w in male: $2-2.8$, in female: 2.4-2.8), face usually microridged medially, in some species basomedially polished in female; TFC partial, with an M-like form, usually strongest medially; malar space long, in male about 1.2 MOD, in female about 2 MOD (less than the measures given in Kimsey \& Bohart, 1991); propodeal angle short, stout, blunt, straight or gently incurved behind; last tergite not saddled, pit row developed, but usually simple, without large pits; apical margin of T3 with four short teeth, usually the median pair a little longer and closer together, lateral pair weak or absent; S2 with two large black spots, sometimes fused or nearly so.

Members of the Chrysis aestiva group are found in the western Palearctic region (15 species and 8 subspecies), and in the Afrotropical region (2 species). They are mostly distributed around the Mediterranean countries, Middle East and West Asia. At present:

- six species and two subspecies are known for the European fauna: Chrysis aestiva aestiva Dahlbom, 1854 (= C. quadrimaculata Bischoff, 1910), C. interjecta interjecta du Buysson (in André), 1895 (=C. rosina Balthasar, 1953), C. interjecta hemichlora Linsenmaier, 1951, C. maderi Linsenmaier, 1959, C. martinella patrasensis Linsenmaier, 1968; C. mixta Dahlbom, 1854; C. monticola Linsenmaier, 1999 (Rosa \& Soon, 2012);

- nine species and three subspecies are known for Middle East and West Asia: C. aestiva aestiva Dahlbom, 1854, C. aestiva moczari Linsenmaier, 1959, C. andreevi Semenov, 1954, C. antakyensis Linsenmaier, 1968, C. aurelia aurelia Balthasar, 1953, C. aurelia palmachinensis Linsenmaier, 1987, C. gusenleitneri Linsenmaier, 1968, C. iocosa Linsenmaier, 1968, C. martinella martinella du Buysson, 1900 (=C. satunini Semenov, 1967), C. martinella solox Semenov, 1954 (= C. klapperichi Balthasar, 1957), C. mirifica Balthasar, 1953, C. sardarica sardarica Radoszkowski, 1890;

- five species and three subspecies are known for northern Africa (C. caudex Linsenmaier, 1968, C. denticula Linsenmaier, 1999, C. interjecta mediana Linsenmaier, 1987, C. monticola Linsenmaier 1999, C. sardarica perrecta Linsenmaier, 1959, C. sardarica lepidula Linsenmaier, 1959);

- two species are recorded from South Africa and Madagascar (C. grootdermensis Koch, 2006 and C. madecassa Mocsáry, 1908).

Chrysis amurensis Semenov, 1967 was included by Kimsey \& Bohart (1991) in the C. aestiva group but, after type examination, it does not share the diagnostic characteristics of the species group and we transfer it into the $C$. splendidula group.

\section{The Iberian species of the $C$. aestiva group}

Before this study, only two species of the $C$. aestiva group were known from the Iberian Peninsula: Chrysis interjecta du Buysson and C. mixta Dahlbom (Mingo, 1994).
However, C. interjecta is not yet recorded for Portugal, whereas $C$. mixta seems to be very common in central and southern Portugal (Mingo \& Gayubo, 1985; Oliveira et al., 2009). Except for an old record from Sines (Lisbon) 15.viii.1956, leg. N. F. d'Andrade (Natur Museum, Luzern, $\mathrm{CH}$ ), all the records of C. mixta are recent and from Costa Vicentina: Algarve: Guia, 17.v.1999, 1 ภ, leg. Baldock; 19, Aljezur, Odeceixe, 1.ix.2008, 19, vii.2009, and 1ð̄, 27.v.2011, leg. A. Livory \& R. Coulomb; 10̄, Pera, Vila do Bispo, 25.ix.2014, leg. I. Cross; 290 , Carrapateira, 14.ix.2014; 2 9, 19.ix.2014, leg. A. Livory \& R. Coulomb; Alentejo: 1ठ, Zambujeira do Mar, 17.vii.2012; $1 \widehat{\jmath}$, leg. A. Livory \& R. Coulomb; 1 , , Vila Nova de Milfontes, 20.ix.2014, leg. A. Livory \& R. Coulomb.

The distributional range of C. mixta is SW European, being distributed only in southern Portugal, Spain, southern France and northwestern Italy (Linsenmaier, 1959; Rosa \& Soon, 2012). Other citations outside this range are referable to other similar species (e.g. Chrysis maderi Linsenmaier, 1959).

Chrysis monticola Linsenmaier is easily recognizable within this species group, and more generally, within the European chrysidid fauna by its unique body colouration combined with diagnostic characteristics of the group. A similarly coloured European species is Chrysis judaica du Buysson (scutellaris group), known only from Cyprus, whereas in northern Africa and Middle East other species share a similar colour pattern, but belong to different species groups (e.g. C. moriceana du Buysson - scutellaris group; C. convexianalis Linsenmaier - facialis group).

\section{Key to Iberian species of the Chrysis aestiva group}

1. T3 apical margin with two small, triangular teeth, sometimes blunted or like simple undulations ... $\boldsymbol{C}$. mixta

- T3 apical margin with four triangular teeth, always distinct in both sexes.

2 . Female with mesosoma bicoloured blue with pronotum, scutellum, metanotum and mesopleuron contrasting red; malar spaces subparallel; T3 with long and triangular teeth, the two median teeth extended distinctly further posteriorly than lateral teeth. Male with greenish to golden green pronotum, scutellum, metanotum and mesopleuron contrasting with the rest of blue mesosoma; shortest distance between the compound eyes narrower than eye width .....

C. monticola

- Female with green to greenish mesosoma, darker bluish to blackish on the mesoscutum; malar spaces convergent; T3 with apical teeth almost aligned along the apical margin. Male with green mesosoma; shortest distance between the compound eyes distinctly larger than eye width

C. interjecta

\section{DISCUSSION AND CONCLUSIONS}

Chrysis monticola Linsenmaier was recently described by Linsenmaier (1999) from northern Africa based on a type series of seven specimens. Until now, no other specimens have been found from the main European collections. Therefore, we cannot evaluate if this species has 
recently dispersed to Portugal from northern Africa or if its original distributional range has been wider in west Mediterranean countries and is now limited to the west Iberian Peninsula and North Africa. It is very likely that C. monticola could be also distributed along the coast of Andalucia, Spain.

\section{Acknowledgments}

We wish to thank Roselyne Coulomb for her support and field research and all the colleagues who collected specimens and shared data with us: J. Smit (Leiden, Netherlands), M. Jenner (Eastbourne, England), G. Allen (Maidstone, England), D. Keen (Seville, Spain), H. Whiteley (Shipley, England), A. Penado (Lisbon, Portugal), C. Reis (Lisbon, Portugal), A. Albernaz Valente (Evora, Portugal), R. Andrade (Porto, Portugal), A. van Harten (Portalegre, Portugal), T. Wood (University of Sussex, England) D. Pinto (Lisbon, Portugal), I. Cross (Dorchester, England). Special thanks to M. Bernasconi (Naturmuseum, Luzern, Switzerland) for his cooperation and assistance in the study of the type material in the Linsenmaier collection, Graham A. Collins (Croydon, England) for providing the map of Portugal, achieved with Dr. Alan Morton's DMap software programme, and to Juho Paukkunen (Helsinki, Finland) for critical review of the manuscript.

\section{REFERENCES}

Balthasar V., 1953 (1951) - Monographie des Chrysidides de Palestine et des pays limitrophes. Acta Entomologica Musei Nationalis Pragae, supplement 2, 27: 1-317.

Buysson R. du, 1891-1896 - Les Chrysides. In: Species des Hyménoptères d'Europe \& d'Algerie. André E. Vve Dubosclard, Paris, Tome Sixième.

Dahlbom A.G., 1854 - Hymenoptera europaea praecipue borealia, formis typicis nonnullis specierum generumve exoticorum propter nexum systematicum associatis, per familias genera, species et varietates disposita atque descripta. 2. Chrysis in sensu Linnaeano. Friedrich Nicolai, Berlin.

Kimsey L.S. \& Bohart R.M., 1991 (1990) - The Chrysidid Wasps of the World. Oxford University Press, New York.

Kock F., 2006 - Snail shells (Mollusca, Gastropoda, Dorcasiidae) as microhabitats in South African deserts, with the description of a new chrysidid wasp (Insecta, Hymenoptera, Chrysididae) discovered by the BIOTA-Southern Africa Project. Mitteilungen aus dem Museum für Naturkunde in Berlin, Zoologische Reihe, 82 (1): 191-197.

Kuhlmann M., 1996 - Contribution to the knowledge of the bee and wasp fauna (Hymenoptera Aculeata) of the Serra da Estrela, Portugal). Boletim da Sociedade Portuguesa de Entomologia, 166 (VI-16): 214-217.

Linsenmaier W., 1951 - Die europäischen Chrysididen (Hymenoptera). Versuch einer natürlichen Ordnung mit Diagnosen. Mitteilungen der Schweizerischen Entomologischen Gesellschaft, 24 (1): 1-110.
Linsenmaier W., 1959 - Revision der Familie Chrysididae (Hymenoptera) mit besonderer Berücksichtigung der europäischen Spezies. Mitteilungen der Schweizerischen Entomologischen Gesellschaft, 32 (1): $1-232$.

Linsenmaier W., 1968 - Revision der Familie Chrysididae (Hymenoptera). Zweiter Nachtrag. Mitteilungen der Schweizerischen Entomologischen Gesellschaft, 41 (1-4): 1-144.

Linsenmaier W., 1987 - Revision der Familie Chrysididae. (Hymenoptera). 4. Teil. Mitteilungen der Schweizerischen Entomologischen Gesellschaft, 60: 133158.

Linsenmaier W., 1999 - Die Goldwespen Nordafrikas (Hymenoptera, Chrysididae). Entomofauna, Supplement 10: 1-210.

Mingo E., 1994 - Hymenoptera Chrysididae. Fauna Iberica. Museo Nacional de Cencias Naturales Consejo Superior de Investigaciones Cientificas, Madrid, 6.

Mingo E. \& Gayubo S.F., 1985 - Contribucion al estudio de los Crisididos de el Algarve (Portugal). (Hym. Chrysididae). Actas do II Congresso Ibérico de Entomologia. Boletim da Sociedade Portuguesa de Entomologia, supplement 1: 37-46.

Mitroiu M., Noyes J., Cetkovic A., Nonveiller G., Radchenko A., Polaszek A., Ronquist F., Forshage M., Pagliano G., Gusenleitner J., Bartalucci M., Olmi M., Fusu L., Madl M., Johnson N., Jansta P., Wahis R., Soon V., Rosa P., Osten T., Barbier Y. \& de Jong Y., 2015 Fauna Europaea: Hymenoptera - Apocrita (excl. Ichneumonoidea). Biodiversity Data Journal, 3: e4186

Mocsáry A., 1908 - Chrysididen von Madagaskar, den Comoren und Ostafrica. In: Reisen in Ostafrika. Voetzkow A. (ed.). 2: 259-263.

Oliveira de N.G., Gayubo S.F., Strumia F., Serrano A.R.M., 2008 (2009) - The cuckoo-wasps (Hymenoptera, Chrysididae) of Douro Internacional and Serras de Aire e Candeeiros Natural Parks and Paúl do Boquilobo Natural Reserve (Portugal). Frustula Entomologica, n.s. 31 (44): 35-51.

Radoszkowski O., 1890 (1889) - Hyménoptères recoltés sur le mont Ararat. Horae Societatis Entomologicae Rossicae, 24: 502-510.

Rosa P. \& Soon V., 2012 - Hymenoptera: Chrysididae. Fauna Europaea, Version 2.5. http://www. faunaeur. org [accessed 1 Dec. 2014].

Semenov-Tian-Shanskij A., 1967 - [New species of gold wasps (Hymenoptera, Chrysididae)]. Trudy Zoologicheskogo Instituta Akademii Nauk SSSR, 43: 118-184. [Article in Russian].

Semenov-Tian-Shanskij A. \& Nikol'skaya M.N., 1954 - Gold wasps (Hymenoptera, Chrysididae) of Tadzhikistan. Trudy Zoologichescogo Instituta Akademiy, Nauk SSSR, 15: 89-137. [Article in Russian].

Tussac H. \& Zumeta J.B., 1999-2004 - Especies de Chrysididae y Bethylidae (Hymenoptera: Chrysidoidea) colectadas en un sabinar de Juniperus thurifera L. en Los Monegros (Zaragoza, España), con otras citas de interés para el Mediterráneo occidental. Lucas Mallada, 11: 197-211. 